\title{
DE EERSTE PUBLICATIËN OVER KOLONIALE ECONOMIE NA NEDERLANDS HERSTEL IN 1813.
}

I.

Met de stichting der Bataafsche republiek en den ongeveer daarmede gepaard gaanden ondergang der Oost-Indische Compagnie was er een ernstige strooming in de openbare meening, dat de beginselen van onze koloniale politiek in Oost-Indië radicaal moesten worden veranderd.

De lezer weet het. In den Compagniestijd werden de inkomsten door de Regeering uitsluitend verkregen door de tusschenkomst van de hoofden. Het Europeesch bestuur stond buiten de bevolking. Het bekommerde er zich niet om, hoe de inlandsche hoofden tegenover hun onderhoorigen optraden. Wel en wee van de massa gingen den overheerscher niet aan. Zoo doende verbond de Compagnie, naar de ideëele voorstelling van Mr. P. Mijer ${ }^{1}$ : "deze hoofden aan zich door banden van erkentelijkheid en belang, $\in n$ bedong in vergelding van deze weldaden slechts eenige voordeelen voor den handel en de leverantie van eenige op de Europische markt gewilde voortbrengselen om niet of tegen geringe prijzen. Het heffen der contingenten en belastingen werd aan de bescheidenheid der Regenten overgelaten, de invordering der producten en leverantien was ook hun aanbevolen, en de instellingen en gebruiken des volks werden met naauwgezetheid geëerbiedigd."

Het bestuur der Compagnie, het college der XVIIen, is stellig niet altijd blind geweest voor het vele afkeurenswaardige in het beheer der regeering te Batavia. Vandaar min of meer scherpe briefwisseling; breed opgezette adviezen ter genezing van de erkende kwalen; instelling van tot hervorming geroepen commissiën: echter alles zonder merk-

1 In zijn levensbeschrijving van Mr. P. G. van Overstraten: zie de aanhaling op bl. 221 , deel $\mathrm{I}, 3^{\text {en }}$ jaargang (1840) van het Tijdschrift voor Nederlandsch-Indië.

Econ. 1915. 
baar practisch gevolg. Ook publicisten lieten zich niet onbetuigd; maar daaronder menschen met door onrechtvaardige behandeling verbitterde gemoederen, die in den vrijen loop hunner gedachien soms door de herinnering aan persoonlijke grieven werden geprikkeld, hetgeen niet kon strekken om de waardeering van overigens ernstige betoogen te verhoogen. Het is intusschen als een gebeurtenis in de geschiedenis der Indische economie te beschouwen, dat uit den wirwar van meeningen geboren werd het lijvige stuk, hetwelk wij kennen als de "Consideratiën en het Advies van de commissie tot de O.-I. zaken aan het staatsbewind der Bataafsche republiek" van 31 Augustus 1803. President dier commissie was de in de kringen dier dagen hoogstaande J. Meerman, zich kenmerkende door "eene zedigheid" - gelijk de manier van zeggen medebracht, "die aan des mans letterkundige verdiensten eenen nieuwen luister bijzette", luidde het huldevol in $1816^{\prime}$. Haar arbeid mocht het resultaat heeten van een strijd in den boezem der commissie, waarin Mr. Nederburgh het conservatieve element vertegenwoordigde en Dirk van Hogendorp meer afdoende hervormingen wenschte ${ }^{2}$. Geformuleerd werden de beginselen in het $\mathrm{Ch}$ arter van 27 September 1804, ook een mijlpaal op Indisch grondwetgevend gebied. Weliswaar kwam het niet in werking; evenmin werd uitvoering gegeven aan. het onder raadpensionaris Schimmelpenninck d.d. 27 Januari 1806 vastgesteld Regeerings-Reglement, hetwelk slechts op enkele punten het voorafgaande niet navolgde; maar zoowel deze stukken en daarbij behoorende instructiën, als de latere Regeerings-Reglementen, te beginnen met 1815, zijn steeds enkel wijzigingen, aanvullingen geweest van

"In de aAlgemeene Konst- en Letterbode", overgenomen door de Bataviasche Courant van 14 September 1816 No. 5, op bl. 3 .

2. Den $6^{\mathrm{n}}$ December 1814 schreef Gijsbert Karel aan. den Souvereinen vorst: «Mijn broeder is eigentlijk de auteur van het Charter van 1803, vervaardigd door eene commissie, waarin hij met Nederburg zat, en waarin de Compagnie's denkbeelden van Nederburg voor de administratieve beginselen van mijn broeder gestreeken hebben." Zie bl. 129 van mijn aTeruggave der OostIndische koloniën" (1910). Over den strijd tusschen D. van Hogendorp en Nederburgh zie een uitnemend critisch oyerzicht in Dr. F. de Haan's Priangan, dl IV, § 2548 v.v. 
hetgeen aanvankelijk in de Consideratiën van 1803 ten grondslag was aangenomen '.

Onder deze meer vrijzinnige koloniale strooming van den

1 Zie mijn in de vorige noot vermeld werk, bl. 163-164. Over de verdiensten der stukken $1802-1806$ heeft zich op helderé wijze uitgelaten een rapport der $4^{\mathrm{e}}$ sectie van den Staatsraad aan koning Lodewijk. In het resumé van dit 100 bladzijden tellende stuk leest men over het aanvangsrapport en hetgeen er uit voortvloeide het volgende:

aLeur rapport contient les bons principes pour l'organisation civile et du pouvoir judiciaire, et même, à l'exception d'un seul point, pour la législation de l'agriculture et du commerce. Le Gouvernement adopta ce rapport, mais corrigea le point essentiel qui nous venons d'indiquer. Il s'agissait d'exclure de la liberté du commerce et de l'agriculture, non setlement la Muscade et'la Gérofle, ainsi que la navigation du Japon, mais encore les deux principales denrées de l'île de Java pour les marchés de l'Europe, le café et le poivre. Le Gouvernement ne put consentir à,cette dernière prohibition, et rendit les deux denrées (le poivre et le café) à l'industrie agricole et commerciale. La Charte arrêtée moyennant cette correction, et quelques autres de moindre importance mais bien vues, passa entrc les mains du Grand-Pensionnaire, qui nomma de nouveaux Commissaires pour l'examiner. Le Rapport de ceux-ci fut conforme en général à la Charte, mais ils opinèrent sur les deux denrées susdites en faveur du monopole. Le GrandPensionnaire alors pésa les avis opposés, et conclut en faveur du commerce libre. Il changea la forme de la Charte en celle d'un Réglement, et dressa une Instruction pour le Gouverneur-Général.

"Telle est, Sire, cette pièce sur laquelle porte la première question de V. M., pièce qui est évidemment le fruit de longues et mûres déliberations, qui ont duré plusieurs années, et à la quelle ont concouru deux commissions et deux Gouvernemens, pièce enfin, qui a réuni tous les avis sur là plupart des points et ne les a laissé partagés que sur un seul point essentiel."

Het rapport was samengesteld door den heer P. van Yzendoorn. Tijdens onze inlijving bij Frankrijk, gaf de regeering te Parijs last om het door den President der sectie geteekende stuk, liggende in de archieven van den Staalsraad te Amsterdam, over te brengen naar de Fransche hoofdstad. Van Yzendoorn had er echter een afschrift van gehouden, hetgeen maar al te weinig van dienst is geweest bij het instrueeren van onzen ambassadeur Fagel te Londen voor de terugverkrijging onzer koloniën in 1814. Het is nu op het Algemeen Rijksarchief te 's-Gravenhage: zie het verslag. over 1013, blz. 156, No. 399 ; «Memorie van P. van Yzendoorn over de koloniẹn, ingezonden bij den Souvereinen Vorst. (1814)." Over dat al tie weinig verg. mijn "Nederlandsch-Indisch bestuur in het midden van 1817" (1915), Alphabetisch register, voce Yzendoorn. 
aanvang der $19 \mathrm{e}$ eeuw, werd de omwentelingsman Daendels geroepen om als gouverneur-generaal van NederlandschIndië nu eindelijk ook eens de daad bij het woord te voegen. De keuze had beter kunnen zijn. Geenszins, dat hij niet krachtig heeft weten op te treden, ook niet, dat hij geen nuttige hervormingen tot stand bracht; maar helder inzicht van hetgeen koloniale economie, met toekomst voor land en volk vorderde, ontbrak hem. Dan ook, zoo Daendels, naar Gibbon's zeggen ": „the best of men, satisfied with the rectitude of their intentions, are subject tot forget the bounds of moderation", geen matiging toonde te kennen, hij was bovendien allesbehalve een best mensch. Vandaar dat hij, met alle waardeering van hetgeen door hem tot stand werd gebracht, reden tot weerzin heeft gegeven, zelfs bij menschen van breed en onbevangen inzicht ". Zoo Elout, als hij in een brief, gedagteekend Batavia, 29 Mei 1816, aan Falck in herinnering brengt Daendels' toost d.d. 7 September 1810 op den "hartelijk dierbaar(en)" koning Lodewijk, zoomede op den "even dierbaar(en)" keizer Napoleon: "Zulke gedragingen in officio!" roept Elout uit ${ }^{3}$. Zoo in een brief d.d. 17 Januari 1817 van denzelfden: "hier ben ik nog meer en meer bevestigd in mijne ongunstige beoordeeling over een groot deel zijner handelingen, die uit meer dan een gezigtspunt verfoeielijk zijn". Zoo Van der Capellen over de oneerlijke toeëigening van Buitenzorg, mede in een brief aan Falck van daar geschreven d.d. 30 December $1816^{4}$ : „Daarover kan maar ééne stem zijn, vooral wanneer men daarbij in aanmerking neemt de wijze waarop Daendels in zijn werk die schandelijke transactie wil doen voorkomen.",

Ik beschouw het als een betreurenswaardige misvatting, dat niet voor de door Daendels ingenomen plaats werd

1 Bl. 336 , dl. I van "The decline and fall of the Roman empire", $4^{\mathrm{n}}$ druk (1906).

? Verg. Falck's Gedenkschriften, bezorgd door Dr. H. T. Colenbrander (1913) over 's mans "geldzucht" en zedeloosheid; bl. 259-260. Ik kom er trouwens op terug.

${ }^{3}$ Op bl. 440 van het werk der vorige noot. - Over Daendels' linderlijk schrijven reeds uit Warschouw d.d. 4 December 1813 aan den erfprins van Oranje, zie de noot op bl, 28 van mijn "Oost-Indië's Herstel in 1816" (1911).

4 In Falck's Gedenkschriften, bl. 464. 
aangewezen Dirk van Hogendorp, reeds in 1803 voor landvoogd bestemd: hij moge dan ook niet in de hoogste beteekenis des woords een best mensch geweest zijn, toèn hadden de omstandigheden van hem nog niet gemaakt, wat men hem over zijn houding a!s gouverneur van Hamburg terecht of ten onrechte verweet en wat stellig in zijn overgaan naar Napoleon in 1814 als afkeurenswaardig moet worden beschouwd. 1 Onmiskenbaar was hij een beter man met een eerlijker hart dan Daendels, in menig opzicht voor schoone menschelijke aandoeningen vatbaar, bovendien, wat aan den Maarschalk-Landvoogd ten eenenmale ontbrak, van diep koloniaal inzicht en van groote ervaring, gelijk hij een en ander reeds in 1799 ten toon spreidde in zijn voortreffelijk „Berigt van den tegenwoordigen toestand der Bataafsche bezittingen in Oost-Indiën en den handel op dezelve".

De voorschriften van het zijnen geest ademend RegeeringsReglement van 1815 werd mede toegejuicht door Raffles, die als luitenant-gouverneur van Java en onderhoorigheden, de grondslagen voor een vrijzinnig koloniaal stelsel trachtte te leggen. Speciaal de artt. 78 en 79 , handelende over de cultures, contingenten en gedwongen leveringen hadden, blijkens zijn History de aandacht getrokken, met voldoening aanwijzende, dat men alzoo op den door hem ingeslagen weg zoude voortschrijden ${ }^{2}$. Bij die artikelen werd namelijk

- Verg. bl. 125 noot 4 en bl. $130-131$ van mijn Teruggave t.a.p. Dirk is tegen de Hamburg-beschuldigingen opgekomen in een in 1814 bij de gebroeders Van Cleef te Amsterdam gedrukte «Memorie van den Generaal Graaf van Hogendorp, ter wederlegging van de nadeelige gerugten en lasteringen, dewelke in veele Couranten, Nieuwspapieren en blaauwe boekjes, tegen hem uitgestrooid zijn, gedurende hij Gouverneur was van Hamburg, ten tijde van de belegering van die plaats." Uittreksels ervan treft men aan in de Vaderlandsche Letter-oefeningen van 1814, Eerste stuk, bl. 669-673. - De lezer, die in dit onderwerp belang stelt, mag niet verzuimen kennis te nemen van een door Paul Holzhausen in 1892 bezorgd werk over aDavout" in Hamburg. Uit het Duitsch is het in het Fransch vertaald door commandant Minart en opgenomen in de afleveringen 1, Februari-1 Juli 1014. van het zoo bijzonder geschikte maandschrift: Feuilles d'Histoire du XVIre au XXe siècle.

2 Zie bl. $161-162$ deel I (1817) van de History: «It must therefore be with peculiar satisfaction that we see, with regard to 
aan de ingezetenen toegestaan: „de vrije cultuur van alle voortbrengselen, welke in 's lands Aziatische Bezittingen kunnen worden gekweekt", terwijl al het gecultiveerde zou zijn "het wettig eigendom van den cultivateur", wiens „vrije en onbelemmerde beschikking daarover" wordt erkend. Hierop worden intusschen twee uitzonderingen gesteld:

$a$. Geen particuliere vrije cultuur van specerijen eri opium;

$b$. "Onverminderd de inrigtingen welke zouden kunnen gemaakt worden omtrent de contingenten en de verpligte leveringen, die bij de overneming dier bezittingen uit de handen der Engelschen bevonden zullen worden in vigeur te zijn."

Wat de instructie, voor de Commissie-Generaal vastgesteld 1 , aangaat, de artikelen, die rechtstreeks of middellijk betrekking hadden op het Landelijk stelsel - den naam waaronder gedurende ruim een halve eeuw het min of meer vrijzinnig karakter der koloniale economie geleid zou worden!zij geven den indruk, dat men geen zeer heldere voorstelling had van het terrein, dat de bepalingen ten deze dienden te beheerschen. Men leest van „de verbetering en uitbreiding der vrije cultuur van alle voortbrengselen, speciaal ook van de katoen, en den daarmede verbonden finantielen staat der Indische bezittingen" (art. 2) - katoen, staat er; dus niet koffie, gelijk men eerder verwachten zou; van „al wat strekken kan tot verbetering van het lot van den gemeenen Inlander" (art. 11); van "naauwkeurige opneming van den staat der landen, ten einde de grondbelasting, bij derzelver eventuele invoering op eenen gelijken en weinig bezwarenden voet te kunnen regelen" (art. 12); van „zoo veel doenlijk, persoonlijk onderzoeken den staat van den Landbouw" (art. 13); van "naauwkeurig onderzoeken den tegenwoor-

the freedom of cultivation, the Dutch government sanctions what we had done, and gives our regulations permanency by embodying them in its colonial policy." Volgt de vertaling der artt. 78 en 79 , waarna aldus wordt besloten over de daarbij erkende rechten van den Inlander op de producten van zijn arbeid: «Let him be maintained in those rights, and the Dutch government will realise a revenue far beyond the amount of their former assessments, without, as formerly, disgracing the Europeans in the eyes of the Asiatic, by their weakness, corruption, and injustice."

1 Verg. bl. 169 v.v. van mijn Teruggave t.a.p. 
digen staat van de contingenten en verpligte leveranciën, aan den Lande toekomende" (art. 19).

Terwijl de Commissie-Generaal, in opvolging dier bepalingen, onder Elout's leiding, aan het werk zou tijgen om de Nederlandsche area van vrijheid in cultuur en handel voor de koloniën te openen, deden zich enkele publicisten in Nederland over de nieuwe beginselen in verschillende richtingen hooren; uitsluitend in Nederland, want Indië zelf was door gemis aan "pers" van zulk een gedachtenwisseling geheel uitgesloten '. Deze schrifturen vormen alzoo een schakel in onze koloniale economische geschiedenis. $\mathrm{Er}$ mag weleens meer bepaaldelijk de aandacht op gevestigd worden, omdat men soms door korte aanhalingen en verwijzingen er naar een zeer onvolledig denkbeeld krijgt én van de waarde dier stukken, én van het verband, waarin zij tot elkander staan, én van de indrukken, die zij hebben teweeg gebracht. In zekeren zin valt wel aan te nemen, dat zij geschreven werden buiten invloed van de Raffles-publicatiën; voor zoover namelijk de bekende „Substance of a Minute on the introduction of an improved system of internal management and the establishment of a landrental for the island of Java, to which are added several of the most interesting documents there in referred" wel niet zoo aanstonds, nadat het te Londen in 1814 gedrukt werd, een groote verbreiding erlangd zal hebben, daar het aanvankelijk niet voor het publiek verkrijgbaar werd gesteld; de reeds vermelde History droeg een meer algemeen karakter, doch verscheen eerst in 1817 , toen onze publicisten reeds lang ten strijde waren getogen ${ }^{2}$

1 Verg. bl. 137 van mijn Herstel t.a.p.

2 In de Van Galenstraat te 's-Gravenhage bevindt zich de voortreffelijk georganiseerde koloniale bibliotheelk van het Koninklijk Instituut voor de Taal-, Land- en Volkenkunde van N.-I. en van het Indisch Genootschap onder den verdienstelijken W. C. Muller. De bruikbaarheid hiervan werd aanzienlijk verhoogd in 1908 door de uitgave van een Catalogus (wordt met vervolgen bovendien bijgehouden). Daar er misschien lezers mijner verhandeling zijn, die de vermelde werken weleens willen raadplegen, verwijs $\mathrm{ik}$, waar ik het geschikt acht, naar bladzijde en nommer van dien catalogus. In het jaarverslag van het Instituut over 1914 bl. XXIII, dl. 70 (1915), wordt terecht gezegd: "Wij mogen trotsch zijn op die bibliotheek, de eenige van dien aard in ons land." 
II.

Het werk, dat na het Herstel aanving ten onzent de aandacht over de wijze van koloniaal bestuur in beslag te nemen en inderdaad dadelijk „insloeg”, was Daendels' „Staat der Nederlandsch Oostindische Bezittingen", in 1808-1811. ${ }^{1}$ De afgetreden landvoogd - om niet te zeggen afgezette, al heeft het er veel van gehad! - verhaalt dus hier zijn eigen bestuur. Zulke boeken schrijft men niet om zichzelf te blameeren en ongevoelig komt men er toe, om zich meer complimenten te maken, dan wel strikt met de waarheid der historie stemt: zoo Daendels, zoo Raffles. Elout schreef d.d. 21 December 1817 uit Batavia aan Falck ${ }^{2}$, dat hij het zoo min den een als den ander kon vergeven, dat zij „uit overdreven liefde voor een aangenomen zienswijze, voor eigen daden, zich op feiten beroepen die à la lettre onwaar zijn" ". Maar laten wij dit zeer eenzijdig karakter daar; het is min of meer aan apologiën eigen; dadelijk echter voeg ik er aan toe, dat anders Falck's Gedenkschriften, ook een apologie, geenszins ontsierd wordt door hinderlijke zelfverheffing. Neemt men kennis van de zakelijke, bedaarde voorstelling van het door Daendels verrichte, - daarvoor hebben misschien Mr. Malecotius en De Waal Senior gezorgd, al was de gansche opzet ellendig ${ }^{*}$ - dan laat zich de heftigheid, waarmede de slechts uit ruim 100 bladzijden bestaande tekst is aangevallen ", niet zoozeer verklaren door de daarin uitgedrukte denkbeelden, als wel door de bittere vijandschap, die zijn bestuur bij zoo velen - en waarlijk niet zonder reden! - had opgewekt. Te kwetsbaarder scheen deze apologie, omdat aan haar samensteller in geen geval het aureool van belangeloos optreden beschermend kon toegekend worden. Het doet ons echter ook begrijpen, dat verstandigen als 'n Gijsbert Karel

1 Catalogus, bl. 68 №. 142.

- Op bl. 450 van Falck's Gedenkschriften.

${ }^{3}$ Het woord zienswijze is abusievelijk bij het drukken uitgevallen.

- Over de geschiedenis der samenstelling zie noot 1, bl. 29 van mijn Herstel t.a.p. en de Literatuuropgaaf, bl. XIII, onder No. 17, van mijn "Nederlandsch-Indisch Bestuur in 1817, tot het vertrek der Engelschen" (1913).

s Behalve het deel tekst nog 3 deelen Bijlagen: een onappetijtelijke verzameling. 
geenszins over Daendels' uiteenzeltingen zoomaar afbrekend vonnis velden. Dit persoonlijke toch had hij enkel als van verre vernomen, geenszins had het hemzelf getroffen, gelijk hem wel was overkomen aan De Kaap door het optreden van gouverneur-generaal Janssens, die bij Gijsbert slecht stond aangeschreven ${ }^{1}$. Het beste bewijs trouwens van hinderlijke vooringenomenheid tegen Daendels is, dunkt. mij, dat zijn publiceerende bestrijders als Van den Bosch, Van Polanen, Engelhard, menschen waren, die, in hun sterk uitsprekend karakter van stokvaste conservatieven, Daendels' hoofdstelling, dat er op het oogenblik voor een vrijzinnig Landelijk stelsel op Java geen plaats was, hadden moeten toejuichen. Toejuichen?? Zij halen hem zoo hard mogelijk door!

De eerste, die zich tegen het werk hooren laat, is Johannes van den Bosch, een man, heet het in die dagen, van „eigene ondervinding, als gewezen bezitter van een Landgoed op Java" 2 : de latere landvoogd van het Cultuurstelsel. Had Daendels zich gehaast, overigens ten koste eener meer ordelijke samenstelling, met de verschijning in 1814 van zijn „Staat", om met Nederlands Herstel weer op den voorgrond te kunnen treden en een goede betrekking machtig te worden, Van den Bosch wil er ook geen gras overheen laten groeien, ten einde de op het punt van vertrek zijnde Commissie-Generaal, benoemd ter overneming van de Oost-Indische koloniën, nog van diens tegenschrift kennis kon nemen. Immers zij. ging daarhenen met de machtiging Raffles' vrijzinnige regeering voort te zetten en Van den Bosch wil voor de bedenkingen ertegen tijdig haar oogen wijd geopend hebben. Toch verweet men hem, dat hij zijn geschrift van 1815 niet eerder had doen verschijnen. Het hield verband met het feit, dat de Regeering zich van den oud-landvoogd van Java had afgemaakt door hem tot gouverneur van onze Goudkust te benoemen. Hoe dat goud den man toeglinsterde. Daar zetelde zelfs, naar hij meende te weten, de koning der Ashantijnen op een massief gouden troon. Nu kocht Daendels bij een

1 Gijsbert Karel's ongunstig oordeel over Janssens in mijn Teruggave, t.a.p. bl. $123-124$.

2 Van den Bosch was o. a. landheer geweest van Soedimara; zie Priangan t.a.p., dl. III, bl. $436 \$ 721$. 
uitdrager te Amsterdam ook een troon, waarop Zijne Majesteit Lodewijk Napoleon had gezeten, een zetel althans met fraai beeldhouwwerk, geborduurde kussens, zijden kwasten, prachtig! Niet dat de nieuwe gouverneur daarop wilde rusten tegenover Zijne Zwarte Majesteit; doch in de hoop hem dien te vereeren en daarvoor in ruil den gouden stoel te bekomen: "het schijnt ongelooflijk", schrijft Falck ${ }^{1}$, „en is echter waar". O, ik wil het best gelooven. Met Nederland's Herstel te Bandjermasin loopen wij aan tegen een sultan, nog mokkende over een diamant, dien Daendels hem afgedwongen had bij het verlaten van dien post; niet dat de Landvoogd hem voor zich had gehouden; echter had het stuk. op vendutie weinig opgebracht, omdat alles met gedeprecieerd papier betaald werd; doch al sierde dan ook Daendels er zijn kleed niet mede, onkiesch gescharrel was het geweest ${ }^{2}$. Nu dan zeilde hij met zijn troon ter Goudkust en ziedaar juist op den zeildag verschijnt Van den Bosch' critiek; dáárom vond een Recensent ${ }^{3}$ het gansch "niet edelmoedig, dat deze Aanmerkingen juist op denzelfden dag, en niet eer, in den Boekhandel kwamen, waarop de gewezen Gouverneur Generaal van Neêrlands Indië, thans tot Opperbevelhebber op de Kust van Guinea aangesteld, derwaarts moest onder zeil gaan, en dus geene gelegenheid had, zich te verdedigen. Zijne Memorie heeft toch reeds lang genoeg het licht gezien, om daarop vroeger 100 bladzijden druks te doen verschijnen!" Een ander beoordeelaar bekeek het tijdstip der publicatie uit het oogpunt van de schade, die er door veroorzaakt kon worden aan de liberale richting, door de Commissie-Generaal, naar men verwachtte, toegedaan. "Juist in het tijdstip", klaagde

1 Op bl. 259 van Falck's Gedenkschriften.

2 Zie over deze geschiedenis, met de vermelde stukken, bl. 36 van mijn verhandeling: «Het afbreken van onze betrekkingen met Bandjermasin onder Daendels en de herstelling van

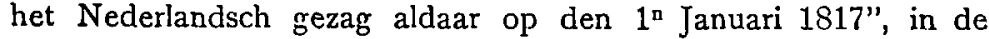
Bijdragen van het Konkinklijk Instituut voor de Taal-, Land- en Volkenkunde van Ned.-Indië, dl. XLIX (1898).

"Zie bl. 40 der "Boekbeschouwing voor 1816" in de Vaderlandsche Letter-oefeningen van dat jaar. Het tijdschrift dier eerste jaren van zijn bestaan vindt men o.a. op de Koninklijke bibliotheek te 's-Gravenhage. 
toch de nader te noemen Campagne ${ }^{1}$, „dat er in Tessel eene expeditie gereed ligt om naar Java te zeilen; - juist in een tijdperk, waarin de Nederlandsche Koophandel, na zoo vele jaren van druk en verguizing, met nieuwen moed zich wil ontwikkelen; en de geest des handels, van al wat verlicht denkt, vooral ten aanzien van Java, hoog gespannen is; en ook onze goede wijze Koning, door alle mogelijke middelen dien edelen geest des werkzamen Nederlanders, kragtdadig ondersteunt" - kwam men aldus roet in het eten werpen.

III.

Het was een vervelende gewoonte dier dagen om aan kleine publicatiën den briefvorm te geven; de verhoudingen in het maatschappelijk leven onderscheidden zich bovendien van de tegenwoordige, dat "vriendschap" er een veel belangrijker plaats innam: ik wil niet zeggen, dat altruïstische gevoelens toen gewichtiger rol vervulden, maar het vriendschapsbegrip deed er in woorden bijzonder opgeld. Men schreef gansche verhandelingen er over! ${ }^{2}$ En dan nog iets kenmerkends op publiciteitsgebied: het schijnt wel, dat de lengte der titels een onafwijsbare voorwaarde was voor het wekken van belangstelling in het gedrukte.

Zoo dan richtte Van den Bosch een „Brief, inhoudende eenige onpartijdige aanmerkingen, op eene memorie, onlangs in het licht verschenen, onder den titel van: Staat der Nederlandsche Oostindische Bezittingen, onder het bestuur van den Gouv.-Generaal H. W. Daendels, . . . 1808-1811" aan een "Vriend" 3. Maar de schrijver, voor de zaken van het koloniale leger verbonden aan een afdeeling van het departement van Oorlog ${ }^{4}$, heeft het misschien minder betamelijk of niet voorzichtig geacht om met zijn naam in te gaan tegen de liberale koloniale strooming van den dag. Zeker is het, dat de "Brief" naamloos verscheen en die terstond den indruk makte een persoon tot steller te hebben: "geheelenal doordrongen met het oude stelsel der Compagnie, 't welk hij, uit sleur, of vooroordeel, of ontzag voor de oudheid,

'Op bl. 9 van zijn op bl. 316 te vermelden "Antwoord".

${ }^{2}$ Verg. dl. I, bl. $4-5$ van mijn inleiding tot de cloor mij bezorgde "Brieven van en aan Mr. H. J. van de Graaff 1816-1826" (1901).

3 Catalogus, bl. 68 No. 138.

- Zie mijn Teruggave t.a.p., bl. 176 vv. 
verdedigt, dan zeer gebrekkig verdedigt", meende de Recensent ${ }^{1}$, vol van "die kleingeestige, bekrompene, van alles wat liberaal heet, afkeerige gronden, waarop, helaas! ons bestuur in de Indiën, tot schande van onzen naam, maar al te lang gerust heeft." Van den Bosch zelf had trouwens ten volle ingezien, dat hij voor het oogenblik den geest des tijds tegen zich had; immers hij liep er reeds op vooruit, wat hij te hooren zou krijgen; maar, verzekerde de "Brief", hij zou „zich de bittere aanmerkingen getroosten, die welligt het gevolg zijn zullen van het gebrekkige zijner pogingen". Overigens leed het stuk in zoover aan hetzelfde euvel, waardoor zich kenmerkte Daendels' „Staat" - men ziet, dat Van den Bosch dezen inderdaad weinig sprekenden naam aanstonds verandert in Memorie, trouwens evenmin een gelukkig gekozen woord - dat de uitgave een weinig slordig bleek te zijn. Van den Bosch verzocht er, gelijk ook Daendels gedaan had! verschooning voor, te kennen gevende, dat de "Brief" was gedrukt "met wat meerder overhaasting, als anders zou geschied zijn", opdat hij nog onder de oogen kon komen van de op haar vertrek staande Commissie-Generaal: vandaar "vele ingeslopen fouten".

De schrijver deed zich alzoo aanstonds kennen als een man van het oude regime; ook later heeft hij dat niet onder zich gehouden. Het strekt hem, nu hij het meende, tot eer; want, zooals toenmaals de richting was, kon het hem slechts' nadeelig voor zijn toekomst schijnen. Aanhoudend heb ik mij dan ook afgevraagd: hoe heeft Elout toch over de richting van zulk een man in twijfel kunnen verkeeren, waar de predilectie voor den gedwongen arbeid er zóó dik op lag. De naamloosheid van het geschrift was hier geen factor; want de schrijver zelf werkte mede om haar ten spoedigste op te heffen. Zonderling! Van den Bosch kon ten aanzien zijner richting gerust de hand aan Daendels rijken; maar als men uit anderen hoofde behoefte aan veroordeeling had of als men "zich als koloniaal staatsman op den voorgrond wenschte te stellen door D. aan te vallen" 2?? In

1 Op bl. 41 der recensie van den Brief in het «Eerste stuk voor 1816. Boekbeschouwing" van de Vaderlandsche Let terOefeningen van dat jaar.

2 Priangan t.a.p., dl. IV, bl. $821, \S 2629$. 
die dagen reeds trekt de aldus ontstane tweeslachtigheid van het strijdschrift spoedig de aandacht; weliswaar zegt men het niet met zoovele woorden van dezen "Brief"; doch, gelijk wij dadelijk zullen zien, Van den Bosch' vriend Van Polanen neemt ook de pen op, ter zijner ondersteuning en alzoo ter afbreking van den "Staat", hetgeen den Recensent zeer ter snede doet opmerken ${ }^{1}:$ "Het is een merkwaardig verschijnsel, dat de Heer Van Polanen, die een gezworen vijand van Daendels is, het nogtans in sommige opzigten met dezen eens schijnt te zijn omtrent de noodzakelijkheid van den ,gedwongen' arbeid der Javanen; terwijl hii een stelsel aanprijst, regelregt strijdig tegen dat der Engelschen, waarvan hij anders een groot en bijna onbepaald bewonderaar is. Zóó doorkruisen zich somtijds denkbeelden en gevoelens!" Nog in onzen nieuwen tijd heeft men voor dit samengaan van Daendels en Van den Bosch geen voldoend geopend oog gehad, voor zoover wij in professor P. J. Blok's "Geschiedenis van het Nederlandsche volk" lezen ', naar aanleiding van Van den Bosch' nader te vermelden werk van 1818 , dat deze "had gepleit voor terugkeer in gewijzigden vorm tot de oude beginselen der O. I. Compagnie", "tege nover Daendels, Raffles en Muntinghe".

Hetgeen in den "Brief" uit een verstandelijk oogpunt hindert en het stuk vermoeiend maakt te lezen, is de grondslag van het betoog, namelijk wat hij ons leert over $\mathrm{H}$ a nd e ls ba la ns. De gedachte is bij mij weleens gerezen of dat punt in die dagen soms ook niet ontaardde in een stokpaard. Het is niet een ieder gegeven, om daarover rationeel anderen in te lichten: 't . vereischt breedere economische kennis en inzicht dan menigeen schijnt vermoed te hebben. Daardoor worden ongenietbare betoogen geleverd; maar toch soms zeer gevaarlijke, omdat min of meer breede opzet van cijfers het gegoochel ermede verbloemt. En Van den Bosch, hoe ijverig zich bewegend ook, was economisch verre van een onderlegd, knap man; zijn optreden in 's Lands vertegenwoor-

"Bl. 196 van het «Eerste stuk voor 1817. Boelibeschouwing" van de Vaderlandsche Letter-Oefeningen van dat jaar: De recensie der nader te vermelden Polanen-Brieven neemt er bl: 195-201 in.

- Op bl. $S$ van dl. VIII. 
diging, waar hij een Indische leening en het ook door hem diep verdorven geldstelsel had te verdedigen - nogwel onder inroeping van 's Heeren naam! - verdient inderdaad geen naam. ${ }^{1}$

Hij stelde op den voorgrond, dat bij handel Java zoo goed als niets in ruil had aan te bieden. Om den Javaan het ruilmiddel uit de handen te kunnen wringen, moet men hem tot het maken ervan noodzaken, d.w.z. dwingen tot het planten van producten, die men te Amsterdam gaarne op de markt zou zien, als koffie. De „Brief" bestrijdt dan ook niet Daendels; natuurlijk niet! daar deze, dat evenzeer inziende, koffij aldus deed planten; maar wegens de geheel ondergeschikte reden, dat de oud-landvoogd de hoeveelheid arbeid, die de Javaan noodig heeft voor de teelt van een bepaald getal koffieboomen, te laag taxeerde ${ }^{2}$. Ziedaar alles, wat het geschilpunt betrof! Ge dwongen arbeid, spatieert hij overigens, kan slechts de voornaamste bron van inkomst leveren, waaruit volgt: „dat de eerste Staatkunde van ons bestuur op dat Eiland strekken moet om dezen arbeid, voor zoo veel ons belang maar eenigzins toelaat, den Javaan min onaangenaam te maken, of liever, om daaraan het aanzien te geven, van eene billijke belasting". En dan de hervormingen van Daendels?? Noch Elout, noch Van der Capellen - wij lazen het - zijn blind geweest voor veel wat te verfoeien is geweest; maar dit weerhoudt hen niet van billijke waardeering. „Hij heeft hier ook goede dingen gedaan, waarvan men nu nut kan trekken", schreef Elout d.d. 17 Januari 1817 aan Falck. „Daendels heeft den toon gegeven", "groote verbeteringen" aanbrengende: d.d.

1 In de vergadering van 1839 op 1840 , dreigende met aftraden als het voorstel niet wordt aangenomen: "In die afzondering zal ik mijn ongelukkig vaderland beklagen en God bidden, dat $\mathrm{Hij}$ het voor die rampen behoede die ik voorzie, en die door geene menschelijke wijsheid - worden aan de regering de noodige middelen geweigerd - kunnen , worden afgeweerd:" Bl. 303, dl. II van "Nederlardsch Indië in de Staten-Generaal" door E. de Waal (1861).

2 Verg. de noot $\dagger$ op bl. 104.dl. I van Daendels' «Staat". In Priangan t.a.p. dl. IV, bl: $812-813$ is geheel juist het conservatief karakter van den "Brief" uiteengezet; atoen Daendels van de baan was, ging Van den Bosch over de zachtheid van het Compagnies-stelsel uitweiden:'. 
4 Juli d.a.v. "Zoo veel schijnt mij zeker toe dat de oude O. I. huishouding gebrekkig en nadeelig was; dat de gouverneur Daendels dezelve van veel gebreken gezuiverd heeft, en wellicht nog meer zou hebben kunnen doen, zoo hij ook voor zich zelven zoo gestreng geweest ware als hij voor anderen scheen te zijn": d.d. 14 Januari 1818. En Van der Capellen over wegenaanleg d.d. 4 Augustus 1816: „Daendels heeft hierin veel gedaan"; ook hij, Van den Capellen, gaat toch niet mede: "in het miskennen van het goede dat door hem gedaan of geprepareerd is, en waarvan ik de bewijzen in loco dikwijls aantreffe", luidt het d.d. 30 December 1816 waardeerend aan Falck '. Doch bij Van den Bosch is zelfs voor de geringste waardeering geen plaats. De "Brief" verklaarde Daendeis' hervormingen deeis onnoodig, deels schadelijk. Ziedaar de Compagniesman pur sang, die inderdaad niet dan lof heeft voor "het schrander doorzigt en het wijs gedrag onzer Vaderen". Hij rekent u ook voor, dat „bij behoud der voormalige inrigtingen, Java nagenoeg $2 \frac{1}{2}$ maal zoo veel voordeel opleveren (zou), als bij die, welke door den Heer Daendels voorgesteld worden". Aldus de Multatuliaansche "perspomp" reeds in den maak, ten bewijze dat het geen ijdele grootspraak zou zijn! Hij wraakt Daendels' geweldplegingen, als den Bantamschen oorlog. Ontkend wordt, dat de knevelarijen op de door Daendels vermelde schaal plaats vonden, zoodat hierdoor geenszins was gemotiveerd het uit elkander nemen van het voormalige Compagniesstelsel. Ook kon geen vrije handel Java redden, ten bewijze waarvan een aantooning wordt gegeven, gelijk een kwartiermeester voor een menage-boek zou in acht nemen. Men krijgt de voorstelling, dat alle ingezetenen van Java te samen moeten verteeren 21 millioen rijksdaalders, terwijl het eiland slechts aan arbeid opbrengt voor 20 ; „en dus in gewone jaren bijna gelijk staan met de behoeften der gezamenlijke ingezetenen". Een kwart van den arbeid ten behoeve van den Staat komt alzoo op een inkomen van 5 millioen; aangezien de handelsbalans echter nadeelig is, verminderen de uitvoerobjecten en wordt het geld steeds schaarscher, waardoor "de Javaan meer en meer in de

1 Zie Falck's Gedenkschriften, bl. 443, 448, 452, 460, 464. 
noodzakelijkheid geraken (zal) van in natura zijne belastingen te voldoen". Doch dat zal niet anders zijn dan rijst of andere niet voor de Europeesche markt geschikte producten: "Hiervan moet alzoo een totale stagnatie het gevolg worden." Kan men dan den Javaan geen koffie doen planten? "Met zijnen vrijen wil, naar mijn inzien, neen." Maar „zoo men hem de vruchten van zijnen overigen arbeid verzekert, door hem onafhankelijk van zijne Regenten te maken", zou dan de Javaan zijn belasting niet in koffie willen opbrengen? "Ik wenschte dat met ja te kunnen beantwoorden; dan ik vrees dat de gevolgen niet aan de verwachting beantwoorden zullen." De Briefschrijver wijst daartoe erop; hoezeer bij "alle volkeren, die nog slechts eenen geringen trap van beschaving bereiken, overweegt de afkeer van den arbeid, de wensch naar genot"; hoezeer "industrie en vlijt dochters zijn van geweld en slavernij".

Van den Bosch' onbekenden "Vriend" moet in denzelfden "Brief" ook nog vernemen: „Eenige aanmerkingen op het stelsel van belasting, thans door de Engelschen ingevoerd, en het vooruitzicht, welke de toekomst belooft". Hij noemt hun Landelijk stelsel „niet nieuw, en evenmin van hunne uitvinding, maar was reeds in dezelfde kolonie bekend, en met verschillende modificatien, op de zoogenaamde vrijmanslanden in werking gebragt”. Erkennend schrijft hij: „Buiten tegenspraak schijnt het eene strekking te hebben, om den ijver van den Javaan op te wekken, door hem in de gelegenheid te stellen, van de vruchten van zijnen arbeid te genieten, en dus den grooten hefboom eigenbelang in beweging te brengen ter bevordering van de industrie en vlijt. Niemand is er, die niet gaarne aan zulk een beginsel regt doen zal." Maar wee de toekomst! Java heeft eigenlijk nooit voordeel gegeven, en het zal nu nog minder worden wegens de vernietiging van de koffiecultuur door de Engelschen, zoodat "het nieuw bestuur zal met eene reeks van moeijelijkheden te worstelen hebben, alvorens het evenwicht tusschen de uitgaven en inkomsten hersteld zal zijn". Onze vaderen waardeerden dan ook niet zoo zeer Java - hier krijgen wij een oorspronkelijk historisch gezichtspunt - „uit hoofde van de pecuniële voordeelen, die hetzelve opleverde, als wel om deszelfs gesclikte ligging voor een stapelplaats van 
hunnen uitgebreiden en voordeeligen handel, gevoegd bij de middelen, die hetzelve, zoo zeer ter verdediging als voeding der andere etablissementen, verschaffen". Overigens achtte de schrijver: "dat op Batavia al het noodige te vinden is, tot eenen uitgebreiden en voordeeligen particulieren handel van haven tot haven in Indië. Indien des Gouvernements inkomsten al niet meer bedragen mogten, dan de uitgaven, dan nog mag men hopen, dat, door den particulieren handel aan te moedigen en van alle nadeelige bepalingen te ontheffen, daarin eene groote mate van welvaart te vinden zal zijn. Het is deze zelfde vrije handel, die, vóór het bestuur van den Generaal Mossel zoo veel tot de welvaart onzer etablissementen bijgedragen heeft, en daarvoor nog altijd vatbaar blijft, omdat op Java artikelen van handel te bekomen zijn, die men elders niet vindt, en wel voor onze kooplieden beter koop, dan voor anderen, en in verscheiden Gewesten van Indië zeer gezocht."

Keert de Briefschrijver zich alzoo vierkant tegen hetgeen het hersteld Nederlandsch-Indisch bestuur zal verordenen in een meer vrijzinnige richting? Het is niet zijn bedoeling: "hoe dit ook wezen moge", merkt hij op, "hoe langzaam de voortgang van industrie en vlijt bij den Javaan ook zijn zal, verdient het gewigt der zaak, er de proef van te nemen, daar hij thans aan het gezag zijner Regenten onttrokken is, schoon ik u niet wil ontveinzen, dat den Javaan te besturen, en koffij te doen planten, buiten den invloed zijner Regenten, mij moeijelijk en zelfs gevaarlijk schijnt. Dan het is eene taak, ons tegenwoordig bestuur waardig, aan een edel beginsel gedurende eenigen tijd het belang te onderschikken." .... „Dan alleen zou ik vreezen, dat het groote doel niet bereikt worden zal, wanneer namelijk het Gouvernement, met eene gretige hand alle voordeelen naar zich slepende, deszelfs welvaart van die der ingezetenen afscheidde. Naar mijn inzien is het een stelregel, dat, wil men voordeelen van een land trekken, men beginnen moet, met die aan hetzelve te bezorgen, met andere woorden, dat men moet zaaijen wil men maaijen."

Aldus de man, die 'n 15-tal jaren later als landvoogd en als minister Indië zou doen uitputten ter wille van het Moederland!

Econ. 1915. 
IV.

In hetzelfde jaar der verschijning van den „Brief”, dus in 1815, gaf Hubertus Dirk Campagne een wederleggend "Antwoord", onder den titel: "Java. Zijnde een kort overzicht van deszelfs waardij en handel' met betrekking tot Nederland" '. Dit boekje van ruim 100 bladzijden maakt een bijzonder weldadigen indruk, deels door het vele feitelijke der mededeelingen, dan door de breede opvatting over handel; verder door den krachtvollen toon over het uitermate groote belang van Java; eindelijk door de aanhoudende prijzenswaardige herinnering aan het gewicht van de rijstcultuur, mede zoo geheel gunstig afwijkend van Van den Bosch' „Brief" 2. Wie en wat was deze schrijver, van wien kort daarna een even degelijk werk zou verschijnen, naar ik nog zal mededeelen? De beide boeken zijn voor mij de éenige uit dien tijd op koloniaal-economisch gebied, die ik nog nù met genoegen kan lezen.

Campagne schijnt een slag van den dichter gehad te hebben, want in Van Polanen's onverkwikkelijk strijdschrift tegen hem wordt hij erover bespot ${ }^{3}$, waarop overigens niet onaardig is gereageerd geworden. Naar hetgeen Campagne zelf mededeelt *, was hij lang vóór de inlijving van Holland bij Frankrijk eerste commies. Tijdens de Fransche omwenteling schijnt hij aan De Kaap werkzaam te zijn geweest. Daarna ging hij er op een notariskantoor: "niet verkozen hebbende, zooals velen, om in den Engelschen dienst over te gaan"; hij bleef er, totdat hij "eindelijk in den jare 1796 de kolonie moest verlaten" en naar Engeland werd opgezonden wegens zijn "volstandige weigering, om na de overgaaf der Kaap in dienst van Engeland over te gaan". Ofschoon slechts negen stuivers daags ter vertering hebbende, wees hij "ook in Engeland alle aanzoeken van de hand en bleef aan mijn land en de beginselen van eer

' Catalogus, bl. 68 No. 130.

2 aIn den aanbouw van rijst alleen, vinden wij eene onuitputbaren bron van rijkdom." "W van dit graan, niet genoeg aan de zorg van het Gouvernement aanbevelen." Bl. 34. Enz.

3 Op bl. 112 van Van Polanen's nader te noemen "Brieven".

' In een nader te vermelden beantwoording aan Van Polanen. 
getrouw". In 1811 zag hij zich "met zoo vele ongelukkigen door den drang der omstandigheden, of liever door honger geperst", de Franschen te dienen en wel als "ontvanger der domeinen en bewaarder der hypotheken" in zijn geboorteplaats Tiel; doch niet willende vergeten Hollander te zijn, werd hij "door gendarmes gewelddadig uit dien post gezet" '

Hoe Campagne zich aanstonds keert tegen hetgeen Van den Bosch feitelijk wil, wordt kernachtig door hem aangegeven ${ }^{2}$, waar hij zoo naar waarheid opmerkt: „Bijzondere kooplieden, door achteloosheid als anderzins verliezen ondergaande, treft zulks onmiddellijk hun eigen beurs. Wanneer Compagnies handel nadeel leed, veroorzaakte dit geene de minste trilling in de koffers harer Dienaren. Een Gouvernement zij dan nimmer koopman." Natuurlijk te volstrekt gezegd; maar zoo was de gansche staathuishoudkunde dier dagen ${ }^{3}$. De schrijver toonde ook dadelijk een breeder inzicht dan Van den Bosch, doordien hij volstrekt niet wilde medegaan met de onbepaalde afkeuring van Daendels' bestuur. Geenszins om er een onbegrensde bewonderaar van te zijn: integendeel, ook hij noemde elnstige grieven. Scherp o. a. werd veroordeeld diens maatregelen tegen de rijstcultuur, die de Landvoogd wel zoogenaamd

1 Wat Campagne hiermede eigenlijk bedoelt, weet ik niet; maar wel blijkt uit deze mededeelingen, dat hij na het Herstel niet het voorbeeld volgde van zoo vele, die het deden voorkomen, dat zij slechts gedwongen een post onder het Keizerrijk hadden aangenomen, omdat $\mathrm{zij}$ anders de pijnlijke gevolgen eener weigering zouden hebben te ondervinden. Zie Falck's opmerking hierover in de Gedenkschriften, bl. 73-74. - Uit een rapport van den departementschef van Koloniën d.d. 31 December 1817 No. 441 aan den Koning, op het Rijksarchief aanwezig, blijkt mij nog het volgende. Onder koning Lodewijk was hij werkzaam op het ministerie van Marine en Koloniën. Dit ministerie tijdens de inlijving opgeheven wordende, ontving hij een pensioen van $151 \overline{5}$ francs of f 721.40. Bij Kon. Besl. d.d. 21 Januari 1815 No. 4 werd hij commies op het departement van Koloniën tegen een traktement van f 1600 . In December 1817 pensioen verzoekende wegens zwakke gezondheid, werd hij bij vermeld rapport in aanmerking gebracht voor een pensioen van $\mathrm{f} 900$. Hij was toen 60 jaar.

2 Zie bl. 88-89 van het boekje.

3 Verg. mijn opmerkingen in deel I, bl. 22 der $V$ an de Graaf-brieven t.a.p. 
had vriigelaten, doch waarvan de uitvoer alleen aan de Regeering werd toegestaan ${ }^{1}$. Maar men behoefde daarom de oogen niet te sluiten voor het goede, dat verricht werd om tot een hoogere opvatting van bestuur te komen, meende de schrijver, opmerkende: „dat de uitwerkselen dier maatregelen, in de gevolgen beschouwd, heilzaam zullen wezen; en dat men van niemand het doorhakken van den gordiaanschen knoop konde verwachten, dan juist van een' man, die zulk een eigendunkelijk karakter en volstandigen wil bezat". En bijna op het einde van het geschrift (bl. 118): „Men had misschien regt, om de wijze waarop de maatregelen door Generaal Daendels genomen, zijn daargesteld, te laken; maar men had mogelijk minder bevoegdheid, om een stelsel af te keuren, dat zulke voorstanders heeft als de leden der Staatscommissie van den jare 1803: en nog wordt voorgegestaan door mannen van aanzien, verstand en belangeloosheid". Er had aan toegevoegd kunnen worden, dat nog in 1814 voor het ontwerpen der koloniale beginselen, waaruit in 1815 het Regeerings-Reglement en de Instructie voor de Commissie-Generaal voortvloeiden, er bij order van den Souvereinen vorst op gewezen werd om ook met Daendels' opvattingen rekening te houden ${ }^{2}$. Voor Java's schoone toekomst doet Campagne een beroep op het door onze Staats-Courant van die dagen gepubliceerd rapport van Mackenzie ${ }^{3}$, waardoor, zijns inziens, in den hoek wordt gezet: „de speelpop der vrienden van het oude stelsel".

1 Daendels' regeling beoogde dus iets anders dan hetgeen tot in de laatste tijden nog wel ten aanzien van rijstuitvoerverbod in practijk wordt gebracht. Over de beteekenis van dit laatste, weidde ik breedvoerig uit in de «Bijdragen tot de Taal-, Land- en Volkenkunde van Nederlandsch-Indië", uitgegeven door het Koninklijk Instituut van dien naam: zie afl. 4 , deel 68 (1913), bl. $472-485$. Op bl. 484 aldaar deelde ik mede, dat per Henriet te Elis abeth door de Indische regeering op het einde van 1817 rijst naar Holland is gezonden. Deze bezending werd o. a. aangevuld, blijkens depêche d.d. 7 Juni 1818 No. 129 van Commissarissen-Generaal met nog 25 lasten of 100.000 u' rijst per Jan en Cornelis, schipper Jacob Duyff. Over de quaestie van een rijstuitvoerverbod zie ook een artikel in het "Koloniaal Tijdschrift" van 1914 No. 2, bl. 145 door Bethbeder.

2 Zie mijn Teruggave t.a.p. bl. 164.

3 Zie mijn Bestuur-1817 t.a.j., bl. 192. 
En dan nevens aldus voorgespiegelde rechtstreeksche voordeelen, de middellijke! 's Mans hooge opvatting ten deze, zoo enorm afwijkend zelfs van de hooggeplaatsten onzer koloniale staatslieden, met hun eindeloos zeuren over "lastposten", is waarlijk verrassend en vernietigend voor het laag bij de grondsche van Van den Bosch. „Gesteld eens”, schreef hij, „dat Java een tekort van een millioen oplevert; doch dat de wederkeerige handelsbetrekkingen van het Moederland en Indiën, de algemeene bron, namelijk de kas der ingezetenen met twee millioenen hadden verrijkt, bestaat er dan geen wezenlijk voordeel van een millioen? immers ja; waarom dan toch voedsel gegeven aan dat dwalend denkbeeld van zoo vele Nederlanders, die bij het verlies van de eene of andere Kolonie zoo gewoon zijn te zeggen: 'ach? wij verliezen er niets aan; het geeft toch geene voordeelen' enz., welk een valsch denkbeeld over de eigenlijke waarde eener Kolonie!" Hij wijst er ook zoo naar waarheid op, dat uit de cijfers van in- en uitvoer volstrekt niets op te maken valt over handelsbalansen, daar de kooplieden waren: „meest ambtenaren; en deze betaalden nimmer eenig regt voor den uitvoer; gelijken vrijdom genoten Regenten, aanverwanten van Pachters, Hoofden der Chinezen, enz. De inkomende regten werden ook maar gedeeltelijk, of in het geheel niet voldaan; de uitvoer genoot echter den meesten vrijdom." Wat had men dus aan een dergelijke statistiek? Doch ook afgescheiden daarvan, verwierp Campagne de verschrikking van een nadeelige handelsbalans, wijl Java's productiefvermogen zoo verhoogd was. Hij verklaarde tot zijn leedwezen nog onbekend te zijn met Raffles' werk over de Landelijke inkomsten, de Substance ${ }^{1}$; echter had hij van een door hem hoog geacht deskundige over het bestuur van den Luitenant-Gouverneur vernomen: „dat hij het Gouvernement meer inkomsten bezorgd heeft dan ooit; maar dat ook tevens daardoor de productive staat van het eiland waarschijnlijk vermeerderd is, en nog vermeerderen zal, als men bij hetzelve blijft. Hij heeft als 't ware de interessen ten koste van het kapitaal verhoogd." Ook die deskundige geloofde niet aan het nadeelige van de handelsbalans.

1 Vermeld hiervóór op bl. 305. - Catalogus, bl. 70 No. 51. 
Is het een lichtzijde van dit voortreffelijk boekje, dat de schrijver, gelijk ik mededeelde, zoo dringend de belangen der rijstcultuur voorstaat, niet minder verdienstelijk is de mede telkens terugkeerende aandrang voor de bevordering van de suikercultuur. "Het is van belang", lezen wij er, "de suikerteelt uit te breiden, vooral sedert de Engelschen zoo werkzaam op Ceilon zijn om er den aanbouw te bevorderen. Suiker is een voorwerp van handel om geheel de west van Indië, Perzië, China en Japan. Zoo de Nederlanders zich door werkloosheid als anderszins dit voordeel evenals den Lijnwaadhandel laten ontnemen, moet men het niet aan Java, maar aan het Bestuur wijten, dat het land niet die voordeelen aanbiedt waarop men rekent, en voor welke het vatbaar is. Het Gouvernement kan omtrent dit artikel de thans naar Indië vertrokken Hooge Ambtenaren misschien niet genoeg aanbevelen, de behartiging der voorgestelde verbeteringen met opzigt tot de Suikerteelt: ampel te vinden in den evengenoemden brief van $4 \mathrm{Juli}$ 1795." Vooral in het licht der latere geschiedenis van de ontwikkeling der suikercultuur werkt deze belangstelling bijzonder sympathiek.

P. H. VAN DER KemP.

$(S \operatorname{lot} v o \lg t)$. 